\title{
Analisis Potensi Kawasan Wisata Kuliner Dalam Mendukung Pariwisata Di Kota Tegal Jawa Tengah
}

\author{
Juliana \\ Fakultas Pariwisata, Universitas Pelita Harapan \\ Email : Juliana.stpph@uph.edu
}

\begin{abstract}
Culinary diversity in the city of Central Java is storing great potential to be developed as a support service in developing the potential of culinary tourism. Culinary tourism is one alternative in addition to other types of tourism choices such as cultural tourism, nature tourism, and marine tourism, especially artificial tourism. formerly known by tourists who come to the city of Central Java. Tegal City actually stores abundant culinary wealth. However, these culinary items have not been packaged in such a way as to attract tourists. The potential of culinary tourism areas in supporting tourism in the city of Tegal aims to lift the image of food made from the city of Tegal so that it is popular with the community and able to compete with modern food. This study was conducted to analyze the potential of culinary tourism in Central Java and identify problems. problems faced in developing culinary tourism in supporting tourism in Central Java. This research is descriptive research using primary and secondary data. The method of data analysis is qualitative descriptive and SWOT Analysis. In conducting data analysis is done by collecting secondary data as well as primary data. Secondary data was obtained from the Tegal city government. Tegal City Tourism Office and Central Bureau of Statistics. Primary data is obtained by interviewing directly with traders or businessmen of typical culinary food stalls in Central Java. Tegal's assets include natural tourism, artificial tourism, religious tourism, campsites and cultural parks, culinary tourism.
\end{abstract}

Keyword : tourism culinary, Tegal city

Abstrak - Keanekaragaman kuliner di kota Tegal Jawa Tengah menyimpan potensi yang besar untuk dikembangkan sebagai jasa penunjang dalam pengembangan potensi wisata kuliner.Wisata kuliner menjadi salah satu alternatif di samping pilihan jenis wisata lainnya seperti wisata budaya, wisata alam, dan wisata bahari, wisata buatan yang sudah terlebih dahulu dikenal oleh wisatawan yang datang ke kota tegal jawa tengah.Kota tegal sebenarnya menyimpan kekayaan kuliner yang melimpah. Akan tetapi kuliner-kuliner tersebut belum dikemas sedemikian rupa untuk menarik minat wisatawan. Potensi kawasan wisata kuliner dalam mendukung pariwisata di kota tegal bertujuan untuk mengangkat citra makanan berbahan dasar pangan kota tegal sehingga banyak digemari oleh masyarakat dan mampu bersaing dengan makanan modern.Penelitian ini dilakukan untuk menganalisis potensi kawasan wisata kuliner di kota Tegal Jawa Tengah dan mengidentifkasi masalah-masalah yang dihadapi dalam mengembangkan wisata kuliner dalam menunjang pariwisata di kota Tegal Jawa Tengah. Penelitian ini bersifat penelitian deskriptif dengan menggunakan data primer dan sekunder. Metode analisa data adalah deskriptif kualitatif serta menggunakan analisis SWOT. Dalam melakukan analisa data dilakukan dengan mengumpulkan data sekunder maupun data primer. Data sekunder diperoleh dari Pemerintah kota Tegal. Dinas Pariwisata Kota Tegal dan Biro Pusat Statistik. Data primer diperoleh dengan mewawancarai langsung dengan para pedagang atau pengusaha warung makanan kuliner khas di kota Tegal Jawa Tengah. Hasil penelitian didapatkan Kota Tegal memiliki banyak kuliner yang dapat dijadikan santapan baik wisatawan yang akan berkunjung ke Kota Tegal, terdapat 27 jenis kuliner yang terdapat di kota Tegal Aset yang dimiliki Tegal antara lain wisata alam, wisata buatan, wisata religi,bumi perkemahan dan taman budaya, wisata kuliner.

Kata Kunci : tourism,culinary,kota tegal

\subsection{Latar Belakang}

Pariwisata adalah kegiatan dinamis yang melibatkan banyak manusia serta menghidupkan berbagai jenis usaha (Ismayani, 2010:1). Menurut Undang-undang Republik Indonesia No. 10 tahun 2009 tentang Kepariwisataan, Pariwisata adalah berbagai macam kegiatan wisata dan didukung fasilitas serta layanan yang disediakan masyarakat, pengusaha, Pemerintah, dan Pemerintah Daerah. Kegiatan wisata terdiri dari tiga komponen utama yaitu wisatawan yang menjadi aktor dalam kegiatan wisata, geografi yang merupakan pergerakan wisatawan dari daerah asal wisatawan, daerah transit dan daerah tujuan wisata, dan industri pariwisata yang menyediakan daya tarik, jasa dan sarana pariwisata (Ismayani, 2010:2-3). Kegiatan 
Pariwisata meliputi beragam orang, aktifitas, dan fasilitas. Segmen spesifik dari pariwisata terdiri dari atraksi dan hiburan, food and beverage, transportasi, travel agency, akomodasi, dan destinasi (Cook, Hsu, \& Marqua, 2014:1-3).

Pariwisata adalah sebuah industri yang di dalamnya terdapat komponen yaitu atraksi wisata, aksesbilitas, amenity atau fasilitas dan ancillary atau organisasi yang mengurus kepariwisataan (Cooper dalam Prasiasa, 2013:52). Dari keempat komponen tersebut pengeluaran cukup banyak dilakukan oleh wisatawan pada amenity yang berhubungan dengan food and beverage Potensi wisata adalah kondisi suatu wisata yang terdiri dari berbagai hal yang mendukung keberadaan objek utama. Hal-hal yang mendukung tersebut berupa kelengkapan flora dan fauna, tingkat kemiringan medan,tingkat aksesbilitas,jumlah wisatawan (Dinas pariwisata Kota Tegal, 2018).

Salah satu daya tarik dalam berwisata adalah wisata kuliner. Wisata kuliner adalah wisata yang berfokus kepada atraksi kuliner, termasuk didalamnya food and beverage yang menjadi salah satu segmen dari pariwisata (Long, 2014:1). Meskipun makanan selalu menjadi bagian dari industri pariwisata, namun hal tersebut baru ditekankan sekitar tahun 1990. Sekarang wisata kuliner telah ada dalam berbagai format seperti jajanan kuliner, kelas memasak, restoran, buku masak, petunjuk makanan, dan resep-resep adaptasi makanan mulai dari bahan-bahan dasar hingga tampilannya. Wisata kuliner tidak hanya meliputi proses produksi dan persiapan saja, namun juga mengenai kebudayaan dari makanan tersebut, orang yang terlibat dalam proses produksi, dan juga akses untuk dapat menikmati makanan tersebut (Long, 2014:1).

Indonesia terkenal akan pariwisatanya, termasuk didalamnya wisata kuliner. Indonesia memiliki 34 provinsi, termasuk salah satunya adalah provinsi Jawa Tengah. Provinsi Jawa Tengah berdiri pada tanggal 4 Juli 1950 dengan dasar hukum Undang-Undang No. 70 tahun 1950. Pemerintahan di Provinsi Jawa Tengah terbagi menjadi 29 kabupaten, 6 kota, 534 kecamatan, 8.540 kelurahan serta 31.820 desa. Salah satunya adalah Kota Tegal. (Komandoko, 2010:149) Kota Tegal Terletak diantara $109^{\circ} 08^{\prime}$ - $109^{\circ} 10^{\prime}$ Bujur Timur dan $6^{\circ} 50^{\prime}-6^{\circ} 53^{\prime}$ Lintang selatan, dengan wilayah seluas $39,68 \mathrm{Km}^{2}$ atau kurang lebih 3.968 Hektar. Kota Tegal berada di Wilayah pantai utara, dari peta orientasi Provinsi Jawa Tengah berada di Wilayah Barat, dengan bentang terjauh utara ke Selatan 6,7 Km dan Barat ke Timur 9,7 Km. (Pemerintah Kota Tegal 2014)
Dilihat dari Letak Geografis, Posisi Kota Tegal sangat strategis sebagai penghubung jalur perekonomian lintas nasional dan regional di wilayah Pantai Utara Jawa (Pantura) yaitu dari barat ke timur (Jakarta-Tegal-SemarangSurabaya) dengan wilayah tengah dan selatan Pulau jawa (Jakarta-Tegal-PurwokertoYogyakarta-Surabaya) dan sebaliknya. Pemerintah Kota Tegal (2014).

Luas Wilayah Kota Tegal, relatif kecil yaitu hanya $0,11 \%$ dari luas Provinsi Jawa Tengah. Secara Administrasi Wilayah Kota Tegal terbagi dalam empat Kecamatan dan 27 Kelurahan, dengan batas administratif sebagai berikut :

a. Sebelah Utara berbatasan dengan Laut Jawa.

b. Sebelah Timur dan Selatan berbatasan dengan Kabupaten Tegal.

c. Sebelah Barat berbatasan dengan Kabupaten Brebes

PDRB merupakan nilai tambah bruto seluruh barang dan jasa yang tercipta atau dihasilkan di wilayah domestik suatu negara yang timbul akibat berbagai aktivitas ekonomi dalam suatu periode tertentu tanpa memperhatikan apakah faktor produksi yang dimiliki residen atau non residen (Budiman, 2018:1). Menurut Badan Pusat Statistik, unit institusi yang mencakup penduduk/rumah tangga, perusahaan, pemerintah lembaga non-profit, dikatakan sebagai residen bila mempunyai/melakukan kegiatan ekonomi di suatu wilayah (Indonesia). Suatu rumah tangga, perusahaan, lembaga non profit tersebut mempunyai/melakukan kegiatan ekonomi di suatu wilayah jika memiliki tanah/bangunan atau melakukan kegiatan produksi di wilayah tersebut dalam jangka waktu tertentu (minimal satu tahun). Kenaikan yang terdapat pada PDRB Kota Tegal sektor akomodasi dan makan minum membuktikan bahwa ada peningkatan pada pariwisata di Kota Tegal. Dari 17 sektor pada PDRB Kota Tegal, sektor akomodasi makan dan minum memiliki rata- rata $5,72 \%$. Hal tersebut dikarenakan Tegal merupakan kota yang sedang berkembang sehingga sektor konstruksi dan perdagangan besar dan eceran; reparasi mobil dan sepeda motor memiliki rata-rata yang cukup tinggi dibandingkan sektor-sektor lainnya.

Kota Tegal mengalami kenaikan pada Produk Domestik Regional Bruto (PDRB) pada sektor akomodasi dan makan minum selama 5 tahun terakhir yaitu dari tahun 2013-2017. Kenaikan tersebut dapat dilihat pada tabel berikut : 
TABEL 1

PDRB Kota Tegal Seri 2010 Atas Dasar Harga Berlaku Menurut Lapangan Usaha Sektor PenvediaanAkomodasi dan Makan Minum Tahun 2013-2017. (Juta

\begin{tabular}{|c|c|c|c|}
\hline No & TAHUN & $\begin{array}{c}\text { Jumlah } \\
\text { (Juta Rupiah) }\end{array}$ & $\begin{array}{c}\text { Persentase } \\
\text { (Dari PDRB Total) }\end{array}$ \\
\hline 1 & 2013 & $493,519.12$ & $5.40 \%$ \\
\hline 2 & 2014 & $557,216.07$ & $5.54 \%$ \\
\hline 3 & 2015 & $613,993.96$ & $5.59 \%$ \\
\hline 4 & 2016 & $706,254.38$ & $5.93 \%$ \\
\hline 5 & 2017 & $799,174.16$ & $6.14 \%$ \\
\hline
\end{tabular}

Berdasarkan Peraturan Pemerintah Nomor 7 Tahun 1986 tentang perubahan Batas Wilayah Kotamadya Daerah Tingkat II Tegal dan Kabupaten Daerah Tingkat II Tegal, Luas Wilayah Kota Tegal adalah $38,50 \mathrm{Km}^{2}$ atau 3.850 Hektar. Namun demikian secara Defacto luas wilayah Kota Tegal mengalami perubahan sejak tanggal 23 Maret 2007 dengan ditetapkannya Peraturan Pemerintah Nomor 22 Tahun 2007 tentang Perubahan Batas Wilayah Kota Tegal dengan Kabupaten Brebes Provinsi Jawa Tengah di Muara Sungai Kaligangsa sehingga luas wilayah Kota Tegal menjadi $39,68 \mathrm{Km}^{2}$ atau 3.968 Hektar (Pemerintah Kota Tegal, 2014).

Berdasarkan Dinas Pariwisata Kota Tegal, Kota Tegal memiliki 12 daya tarik wisata yang terbagi menjadi lima kategori antara lain dua daya tarik wisata alam, empat daya tarik wisata buatan, empat daya tarik wisata religi, satu bumi perkemahan, dan satu taman budaya, serta wisata kuliner

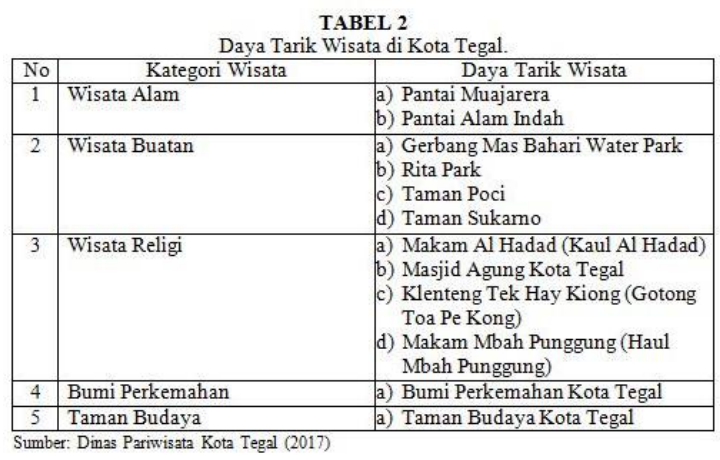

Pengembangan sektor pariwisata Indonesia merupakan salah satu upaya untuk pembangunan di bidang ekonomi karena sektor pariwisata mampu berkontribusi terhadap perekonomian Negara. Potensi wisata yang dimiliki Jawa tengah tersebar di 35 kabupaten/kota termasuk di dalamnya kabupaten Tegal. Kemajuan ilmu pengetahuan dan teknologi telah membawa dampak yang sangat besar bagi dunia pariwisata dengan semakin ketatnya persaingan. Dapat dilihat setiap orang mempunyai kesibukan dan kegiatan masing-masing, sehingga menimbulkan rasa kebosanan, ketegangan dan kejenuhan. Pada saat mereka mempunyai waktu luang atau senggang, mereka akan menggunakannya dengan baik dan bermanfaat sesuai dengan apa yang mereka inginkan. Untuk memulihkan kejernihan pikiran, mendapatkan inspirasi baru, bersenang-senang dan kesegaran baru, mendapatkan inspirasi baru, bersenangsenang dan kesegaran baru, itulah tujuan mereka ketika mereka merasakan bosan, jenuh, dan tegang setelah melakukan aktifitas yang mereka kerjakan. Salah satu kegiatan yang dapat dilkukan untuk mengisi dan mendapatkan apa yang mereka inginkan adalah dengan wisata. Banyak sekali objek wisata dan daya tarik wisata domestik ataupun mancanegara untuk berkunjung. Objek wisata dan daya tarik wisata tersebut tersebar di seluruh tanah air dengan berbagai macam perbedaan kebudayaan dan keunikan yang dimiliki tiap-tiap daerah, salah satunya Kota Tegal. Sektor pariwisata itu barangnya sleeping giant, artinya adalah raksasa tidur, apabila pelakunya mengemasnya, menggerakkannya,ini dapat benar-benar menjadi suatu yang luar biasa sekali. Dampaknya kepada daerah tentu saja dengan peningkatan dari perekonomian. Untuk itu Kota Tegal rasanya sangat siap untuk dapat mempromosikan diri di bidang kuliner, termasuk warteg yang sudah dikenal secara nasional bahkan mendunia, juga dengan budaya macinya, minum teh poci dengan budaya musyawarahnya. Makanan, wisata,potensi lokal adalah suatu daya tarik yang perlu sentuhan khusus, Berdasarkan latar belakang di atas maka dapat dirumuskan permasalahan sebagai berikut :

1. Apakah terdapat potensi kawasan wisata kuliner di kota tegal ?

2. Apakah terdapat peranan penting dalam pengembangan potensi wisata kuliner di kota tegal?

Tujuan dari penelitian yang dilakukan oleh penulis adalah:

1. Untuk menganalisis potensi wisata kuliner dalam mendukung pariwisata di kota tegal

2. Untuk menganalisis peranan penting dalam pengembangan potensi kawasan wisata kuliner dalam mendukung pariwisata di kota tegal.

\subsection{Kajian Pustaka}

1. Pariwisata

Pariwisata menurut Barrows,Powers dan Reynolds (2012,hal.427-428) adalah kumpulan dari banyak bisnis yang produktif dan organisasi-organisasi pemerintah yang melayani para wisatawan yang bepergian jauh dari rumahnya.

2. Potensi Wisata 
Suatu wilayah dapat dikembangkan apabila ada sumber daya alam berupa mineral, sumber air, lahan yang subur, sumber hewani dan nabati atau sejenisnya dilengkapi dengan sumber daya manusia berupa tingkat pendidikan yang memadai, tingkat kebudayaan yang tinggi, tingkat teknologi dan modal yang cukup memadai untuk dapat menggali dan mengembangkan sumber daya alami yang tersedia guna kemakmuran dan kesejahteraan umat manusia (Bintarto dalam Karim ,2003,hal.19).

3. Sejarah Kota Tegal

Secara historis dijelaskan bahwa eksistensi dari Kota Tegal tidak lepas dari peran Ki Gede Sebayu. Bangsawan ini adalah saudara dari Raden Benowo yang pergi kearah Barat dan sampai di tepian sungai Gung. Melihat kesuburan tanahnya, Ki Gede Sebayu tergugah dan berniat bersama-sama penduduk meningkatkan hasil pertanian dengan memperluas lahan serta membuat saluran pengairan. Daerah yang sebagian besar merupakan tanah lading tersebut kemudian dinamakan Tegal. Selain berhasil memajukan pertanian, dia juga merupakan ahli agama yang telah membimbing warga masyarakat dalam menanamkan rasa keimanan kepada Tuhan Yang Maha Esa. Atas jasanya tersebut, akhirnya dia diangkat menjadi pemimpin dan panutan warga masyarakat. Kemudian oleh Bupati Pemalang dikukuhkan menjadi sesepuh dengan pangkat Juru Demung atau Demang. Pengangkatan Ki Gede Sebayu menjadi Pemimpin Tegal dilaksanakan pada perayaan tradisional setelah menikmati hasil panen padi dan hasil pertanian lainnya. Perayaan tersebut tepat di bulan purnama tanggal 15 sapar tahun EHE 988 yang bertepatan dengan hari Jumat Kliwon 12 April 1580. Tahun EHE merupakan umur 355 hari dalam konsep penanggalan Jawa. (Bashori 2014, hal .252) Dalam perayaan juga dikembangkan ajaran dan budaya agama Islam yang hingga sekarang masih berpengaruh pada kehidupan masyarakat.Hari, tanggal dan tahun $\mathrm{Ki}$ Gede Sebayu diangkat menjadi Juru Demung itu ditetapkan sebagai hari jadi Kota Tegal dengan peraturan Daerah No.5 tahun 1988 tanggal 28 Juli 1988. (Pemerintah Kota Tegal 2014)

4. Wisata Kuliner

Wisata kuliner adalah wisata yang berfokus kepada atraksi kuliner, termasuk didalamnya food and beverage yang menjadi salah satu segmen dari pariwisata.
(Long 2014, hal 1). Kota Tegal memiliki banyak kuliner yang dapat dijadikan santapan baik wisatawan yang akan berkunjung ke Kota Tegal.

\subsection{Metode Penelitian}

Penulis menggunakan pendekatan penelitian bersifat kualitatif untuk penelitian potensi kawasan wisata kuliner dalam mendukung pariwisata di kota tegal. Penelitian kualitatif adalah metode penelitian yang berlandaskan pada filsafat post positivism, digunakan untuk meneliti pada kondisi objek yang alamiah dimana peneliti sebagai instrument kunci,data kualitatif merupakan data dalam bentuk kata-kata berupa wawancara,focus group discussion, transkripsi rekaman video,laporan pengalaman (Sekaran\& Bougie, 2016) Penulis mendapatkan data primer dengan melakukan wawancara kepada tiga warga kota tegal yang merupakan pedagang di pasar pondok makan Jalan Teri. Penulis mendapatkan data sekunder melalui Badan Pusat Statistik Kota Tegal,Pemerintah Kota Tegal dan Dinas Kepemudaan dan Olahraga, dan Pariwisata Kota Tegal atau DISPORAPAR yang berlokasi di Jl. Melati No.30A, Kejambon Kota Tegal, Jawa Tengah. Penulis melakukan observasi, wawancara, dan analisis dokumen untuk teknik pengumpulan data. Instrumen penelitian yang digunakan meliputi daftar pertanyaan wawancara dan alat pendukung lain. Aktivitas pada analisis data yaitu dengan mengumpulkan data, mereduksi data, menyajikan data, dan penarikan kesimpulan. Data sekunder adalah informasi yang didapatkan dari sumber yang telah ada seperti data perusahaan, data yang diperoleh dari pemerintahan dan industri yang disediakan oleh media, website, internet dan buku-buku dan lainnya (Sekaran and Bougie,2016). Metode analisis yang digunakan penulis dalam melakukan penelitian ini adalah analisis deskriptif dan metode analisis SWOT. Menurut Enz (2016) analisis SWOT merupakan sebuah alat strategis yang digunakan untuk mengevaluasi kekuatan,kelemahan peluang serta ancaman dalam sebuah organisasi. Analisis SWOT juga terbagi dalam dua bagian yaitu internal environment analysis dan external environment analysis (Kotler dan Keller,2016)

\subsection{Hasil dan Pembahasan}

Kota Tegal adalah salah satu dari 35 kota/kabupaten di wilayah provinsi Jawa Tengah. Dalam perkembangan menuju persaingan bebas pemerintahan kota Tegal selalu menggali potensi-potensi yang ada. 
Kota Tegal berlokasi sangat strategis sebagai tempat transit bagi para pengguna jalan dari Jakarta menuju Jawa dan atau sebaliknya dari Jawa menuju Jakarta. Para pengguna jalan dari jarak jauh, umumnya merasa kelelahan ketika memasuki Kota Tegal sehingga memerlukan waktu untuk melakukan istirahat. Beberapa pengguna jalan ada yang hanya berhenti sebentar tetapi ada juga yang menginap selama masa istirahat sehingga dapat menjadi sumber pendapatan bagi masyarakat maupun pengusaha di Kota Tegal (kuliner, penginapan,transportasi, dan sebagainya). Kota Tegal memiliki banyak kuliner yang dapat dijadikan santapan baik wisatawan yang akan berkunjung ke Kota Tegal. Terdapat banyak wisata kuliner yang terdapat di Kota Tegal. Penulis telah merangkum 27 jenis kuliner yang terdapat di kota Tegal. 27 jenis kuliner ini dibagi dalam delapan kategori yaitu kupat, nasi, sate, jajanan, gorengan, oleh-oleh, dan minuman khas.

Makanan Kuliner kota Tegal yang direkomendasikan adalah Tahu Aci, Nasi Lengko, Sate Ayam Margasari, Sate Kambing Batibul, Soto Tauco, Kupat Glabed, Kupat Bongkok, Kupat Blengong, Nasi Bogana, Nasi Rames, Ponggol Setan, Gelotak, Tempe Gembus, Olos, Pia Argasari Pilus Kletuk, Krupuk Antor, Kacang Bogares, Kacang Klitik, Kecap Djoe Hoa (Wisata Tegal, 2013).

Selain itu, ada juga kuliner di Kota Tegal lainnya seperti Kue Tempel, Kue Kamir, Serabi Bu Rochimah, Rujak Teplak, Es Sagwan, Es Salju dan teh Teh Tong Tji yang menglegenda (Giong-Giong, 2019).Kuliner tersebut merupakan kuliner khas Kota Tegal yang tidak boleh dilewatkan saat berkunjung ke Kota Tegal.

1. Potensi Wisata Kuliner Kota Tegal

Makanan dan minuman sebagai salah satu wujud kebudayaan hasil karya manusia merupakan kebutuhan mendasar yang harus dipenuhi. Pada masa kini, jenis makanan yang telah ada pada masa lampau berkembang menjadi makanan tradisional. Beberapa jenis makanan telah ada pada masa Jawa Kuno, ada yang masih bertahan sampai sekarang dan banyak juga yang telah hilang. Oleh karena itu sangat perlu kembali mengenali jenis-jenis makanan dan minuman Jawa Kuno, merupakan asset budaya yang dapat dimanfaatkan untuk kepentingan pariwisata. Berwisata merupakan salah satu kebutuhan manusia. Rekreasi,relaksasi, keingintahuan, mencari pengalaman, sensasi, kekaguman, pendidikan, kenikmatan,nostalgia,keindahan dan beberapa alasan lainnya. Membuat oarng untuk melakukan perjalanan ke berbagai destinasi untuk menikmati berbagai produk pariwisata dan fasilitas yang tersedia. Tegal merupakan daerah wisata kuliner yang berpotensi dapat mempromosikan diri di bidang kuliner termasuk warteg yang sudah dikenal secara nasional maupun mendunia juga dengan budaya mocinya,minum teh poci sambil bermusyawarah. Tegal terkenal dengan kuliner nasi lengko, tahu aci,soto tauco, nasi rames dan nasi bogana. (Wisata Tegal, 2013).

2. Peranan Penting Wisata Kuliner Dalam Pengembangan Pariwisata di Tegal Kawasan Wilayah Tegal cukup terkenal dengan banyaknya potensi yang terdapat di dalamnya. Hal ini tentu saja berpengaruh terhadap kunjungan wisatawan. Saat ini kuliner sudah merupakan sebuah gaya hidup yang tidak dapat dipisahkan dari kehidupan seharihari karena makanan adalah sebuah kebutuhan sehari-hari. Terutama pada saat sedang berwisata, wisatawan membutuhkan makanan dan yang dicari adalah makanan khas dari destinasi wisata. Makanan biasa terdapat pada restoran. Restoran merupakan suatu tempat yang menyediakan makanan dan minuman untuk dikonsumsi oleh tamu, sebagai kebutuhan yang sangat mendasar akan makan dan minum dalam rangka memulihkan kembali kondisinya yang berkurang setelah melakukan suatu kegiatan sehingga bisa kembali ada stamina yang semula (Wiwoho, 2008:1). Aset yang dimiliki Tegal antara lain wisata alam, wisata buatan, wisata religi,bumi perkemahan dan taman budaya, wisata kuliner. Wisata kuliner merupakan salah satu asset Tegal yang tidak asing lagi bagi wisatawan akan tetapi asset ini perlu perbaikan, pengembangan, dimanfaatkan, dan dilestarikan.

Pengaruh wisata kuliner terhadap perkembangan pariwisata di Tegal dapat dilihat dari analisis SWOT. Sifat dari analisis SWOT sangat situasional, artinya hasil analisis tahun sekarang, belum tentu akan sama dengan hasil analisis pada tahun yang akan datang. Biasanya hasil analisis akan banyak ditentukan oleh faktor-faktor situasi dan kondisi ekonomi, politik dan stabilitas keamanan, dan keadaan sosial yang melatar belakanginya.Keempat faktor SWOT perlu mendapat perhatian yang seksama. Kekuatan harus diperhatikan sebaik-baiknya, kelemahan 
harus dihilangkan dengan segera, kesempatan atau peluang hendaknya segera dimanfaatkan, ancaman atau tantangan harus segera diantisipasi. Dengan cara demikian, dapat diambil langkah-langkah perbaikan, sehingga lebih banyak wisatawan datang, lebih lama menginap dan lebih banyak wisatawan yang membelanjakan uangnya selama melakukan travelling $(\mathrm{Enz}, 2016)$

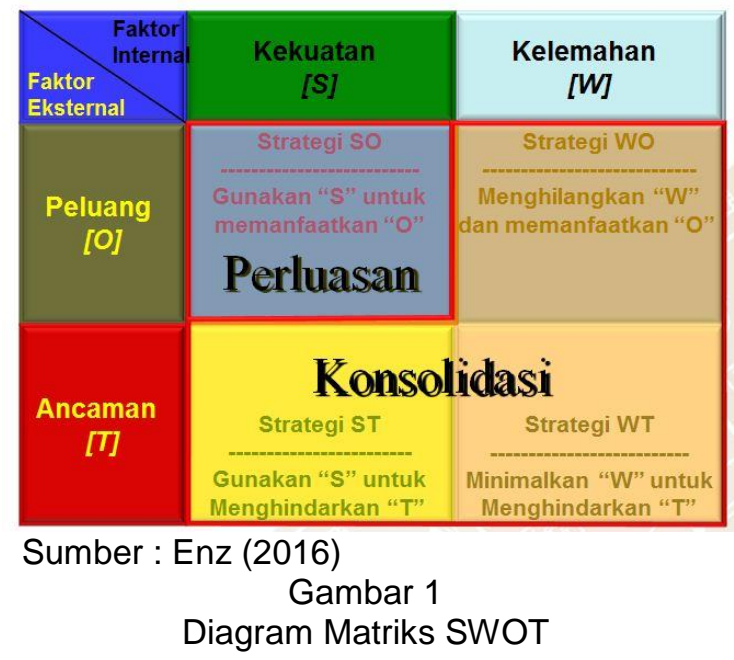

Berikut ini merupakan analisis SWOT wisata kuliner di Tegal berdasarkan observasi yang penulis lakukan serta berdasarkan hasil wawancara kepada pihak pengelola wisata tegal di Tegal :

Kekuatan ( Strength)

1. Tersedianya sarana dan prasarana menuju objek wisata dan waktu tempuh dari terminal sangat dekat

2. Tingginya minat wisatawan yang ingin berkunjung ke Tegal dan tersedianya restoran dan rumah makan yang sangat dibutuhkan wisatawan.

3. Adanya makanan khas yang menjadi potensi, jika dikelola dan dikembangkan secara terpadu dan professional akan menarik minat wisatawan

4. Adanya dukungan pemerintah dalam pengembangan potensi wisata kuliner Tegal

Kelemahan (Weakness)

1. Kurangnya kesadaran kebersihan para pelaku wisata kuliner dalam mengelola wisata kuliner

2. Kondisi sarana dan prasarana yang perlu ditata ulang secara professional untuk memberikan rasa aman dan nyaman bagi wisatawan

3. Kurangnya modal yang dimiliki pelaku wisata kuliner untuk mengembangkan produksinya
Peluang (Opportunity)

1. Potensi dan sumber daya alam yang ada sebenarnya sangat memadai untuk dikembangkan

2. Seiring perkembangan pariwisata di Tegal yang dapat membawa dampak positif terhadap wisata kuliner di Tegal

3. Dapat menjadi salah satu aspek penting pendukung perkembangan pariwisata apabila dikelola dengan baik dan secara professional.

Ancaman (Threat)

1. Daya tarik wisata kuliner belum begitu mendominasi

2. Banyaknya warteg atau rumah makan yang bermunculan dengan produk yang sama sehingga menimbulkan persaingan

Setelah analisis SWOT dilaksanakan, strategi tersebut dapat dikembangkan dalam hal berikut ini :

Strength - Opportunities Strategies

1. Melakukan inovasi, baik pada produk, fasilitas, maupun keunggulan teknologi.

2. Melakukan promosi secara efektif

3. Bekerjasama dengan pemerintah Kota Tegal untuk pengembangan potensi wisata kuliner Kota Tegal

Weakness- Opportunities Strategies

1. Melakukan sosialisasi tata cara pengelolaan yang baik dalam penggunaan sarana dan prasana serta pengetahuan mengenai hygiene sanitasi serta peranan penting wisata kuliner Kota Tegal

2. Mencari investor atau pinjaman modal usaha

3. Mengadakan kerjasama dengan pemerintah kota Tegal dan pihak akademisi dalam membuat buku referensi kota Tegal yang mencerminkan nilai khas sejarah Kota Tegal dan Kuliner Kota Tegal

Strength - Threat Strategies

1. Meningkatkan serta menjaga standar kualitas produk dan layanan

2. Bekerjasama dengan food blogger untuk mempromosikan wisata kuliner di Kota Tegal

Weakness- Threat Strategies

1. Mendorong dan mendukung para penyedia kuliner untuk mengurus standar hygiene dan sanitasi bagi kenyamanan para wisatawan

2. Menggunakan sumber daya yang ada secara efisien dan efektif

3. Mengelola keuangan dengan baik

4. Menjaga kualitas produk dan service 


\subsection{Kesimpulan}

Tegal merupakan daerah yang memiliki banyak sekali potensi dan daya tarik wisata. Tegal memiliki 12 daya tarik wisata yang terbagi menjadi lima kategori antara lain dua daya tarik wisata alam, empat daya tarik wisata buatan, empat daya tarik wisata religi, satu bumi perkemahan, dan satu taman budaya, serta wisata kuliner

Sebagai salah satu keunggulan di bidang pariwisata, wisata kuliner memiliki potensi yang sangat besar untuk dikembangkan dan dimanfaatkan bila dikelola secara professional dan tertata rapi bahkan mungkin menjadi daya tarik tersendiri yang dapat menambah minat para wisatawan untuk datang berkunjung ke Tegal pada khususnya dan menghasilkan devisa di sektor pariwisata. Di Tegal sendiri keberadaan wiasta kuliner juga berperan dalam perkembangan industry pariwisata. Para pelaku wisata kuliner di Tegal juga menghadapi kendala. Jadi para pelaku wisata kuliner masih perlu melakukan perbaikan guna untuk lebih meningkatkan mutu dan daya tarik supaya dapat mengikuti perkembangan jaman. Usaha yang dilakukan pemerintah kota Tegal dalam melakukan perkembangan di dalam industri wisata kuliner sudah cukup baik. Dapat dilihat dukungan dari pemerintah dalam mengembangkan wisata kuliner di Tegal dari diadakannya festivalfestival kuliner, diberikannya penyuluhanpenyuluhan kepada pelaku wisata kuliner dengan tujuan agar wisata kuliner di Tegal dapat mengikuti perkembangan dan tidak meninggalkan ciri khas dari suatu daerah.

Kendala yang dihadapi oleh para pelaku wisata kuliner di Tegal tidak begitu banyak. Salah satu kendala yang sering dihadapi oleh kebanyakan pelaku wisata kuliner adalah kendala modal. Akan tetapi para pelaku wisata kuliner di Tegal memiliki niat yang sangat besar untuk menjaga dan mengembangkan serta melestarikan wisata kuliner di Tegal dan mendapatkan dukungan dari pemerintah.

\section{Daftar Pustaka}

[1] Badan Pusat Statistik. (2018). Konsep Residen dan Non-Residen. Home page on-line. Diakses dari https://www.bps.go.id/subject/52/produkdomestik-regional-bruto--lapangan-usaha.html.

[2] Bashori, M.H. (2014). Penanggalan Islam: Peradaban tanpa penanggalan, inikah kita?. Jakarta: Quanta.
[3] Budiman, W. (2018). Produk Domestik Regional Bruto Menurut Lapangan Usaha Kota Tegal 2013-2017. Tegal: Badan Pusat Statistik Kota Tegal.

[4] Cook, R. A., Hsu, C. H. C., Marqua, J. J. (2014). Tourism: The Business of Hospitality and Travel (5th ed.). New Jersey: Pearson.

[5] Dinas Pariwisata Kota Tegal. (2017). Es Sagwan, Es Gurih Khas Kota Tegal yang Melegenda. Home page on-line. Diakses dari

http://pariwisata.tegalkota.go.id/index.ph $\mathrm{p} /$ wisata-kuliner.

[6] Dinas Pariwisata Kota Tegal. (2017). Ragam Wisata Kota Tegal. Home page on-line. Diakses dari http://pariwisata.tegalkota.go.id/index.php/ wisata-belanja-2.

[7] Enz, Cathy A. (2016), Hospitality Strategic Management:Concepts\&Case, $2^{\text {nd }}$ ed. John Wiley\&Sons,Inc.,Hoboken, New Jersey

[8] Giong-Giong (2018) diwawancara oleh Maria Rosa Alina (Rekaman). Wawancara mengenai kuliner kota Tegal.

[9] Ismayani. (2010). Pengantar Pariwisata. Jakarta: PT Gramedia Widisarana Indonesia.

[10]Komandoko, G. (2010)., Ensiklopedia Pelajar dan Umum. Yogyakarta: Pustaka Widyatama.

[11]Long, L. M. (2014) Encyclopedia of Food and Argicultural Ethnics: Culinary Tourism. Diakses dari https://doi.org/ 10.1007/97894-007-6167-4_416-1.

[12] Pemerintah Kota Tegal. (2014). Arti dan Lambang Kota Tegal. Home page on-line. Diakses dari http://www.tegalkota.go.id/v2/index.php/ka mi/profil-kota/arti-makna-lambang-kotategal.

[13]Pemerintah Kota Tegal. (2014). Letak Geografis dan Luas Wilayah Kita Tegal. Home page on-line. Diakses dari http://www.tegalkota.go.id/v2/index.php/ka $\mathrm{mi} /$ profil-kota/kondisi-geografis.

[14] Pemerintah Kota Tegal. (2014). Sejarah Kota Tegal. Home page on-line. Diakses dari

http://www.tegalkota.go.id/v2/index.php/ka $\mathrm{mi} /$ profil-kota/sejarah-kota-tegal.

[15]Republik Indonesia. Kementerian Pariwisata. (2009). Undang-Undang Republik Indonesia Nomer 10 Tahun 2009 Tentang Kepariwisataan. Diakses Dari http://www.kemenpar.go.id/userfiles/file/46 36_1364_UUTentangKepariwisataannet1. pdf.

[16] Republik Indonesia. Presiden Repbulik Indonesia. (1986). Peraturan Pemerintah 
no. 7 Tentang Perubahan Batas Wilayah Kotamadya Daerah Tingkat II Tegal dan Kabupaten Daerah Tingkat II Tegal. Diakses dari http://ditjenpp.kemenkumham.go.id/arsip/ln /1986/pp7-1986.pdf.

[17] Republik Indonesia. Presiden Republik Indonesia. (2007). Peraturan Pemerintah no. 22 Tahun Tentang Perubahan Batas Wilayah Kota Tegal dengan Kabupaten Brebes Provinsi Jawa Tengah di Muara Sungai Kaligangsa. Diakses dari file:///C:/Users/User/Downloads/PERATUR AN-PEMERINTAH-NOMOR-22-TAHUN2007.pdf.

[18] Salsabila, A. (23 April 2015). Teh Tegal Itu Memang Beda, Rasanya Sepet dan Kentel. Diakses dari https://www.ditegal.com/teh-tegal-itumemang-beda-rasanya-sepet-dan-kentel/.

[19]Sekaran, U. dan Bougie, R. (2016). Research Method for Business: a Skill building approach. (7th ed.). New Jersey: John Wiley \& Sons,inc.

[20]Stauffer, M. D. dan Capuzzi, D. (2016). Human Growth and Development Across the Lifespan: Application for Conselors. New Jersey: John Wiley \& Sons,inc.

[21]Wiwoho, A. (2008). Pengetahuan Tata Hidang. Jakarta: Penerbit Erlangga.
[22]Wisata Tegal. (2013). Daftar Kuliner Tegal. Home page on-line. Diakses dari https://wisatategal.com/kulinerarsip.html.

[23]Pemerintah Kota Tegal (2014). Arti dan Lambang Kota Tegal. Home page on-line. Diakses dari http://www.tegalkota.go.id/v2/index.php/ka $\mathrm{mi} /$ profil-kota/arti-makna-lambang-kotategal; internet; accessed on 1 Oktober 2018.

[24] Pemerintah Kota Tegal (2014). Letak Geografis dan Luas Wilayah Kita Tegal. Home page on-line. Diakses http://www.tegalkota.go.id/v2/index.php/ka $\mathrm{mi} /$ profil-kota/kondisi-geografis.

[25] Pemerintah Kota Tegal (2014). Sejarah Kota Tegal. Home page on-line. Diakses dari

http://www.tegalkota.go.id/v2/index.php/ka mi/profil-kota/sejarah-kota-tegal.

[26]Stauffer, Mark D dan Capuzzi, David. (2016). Human Growth and Development Across the Lifespan: Application for Conselors. New Jersey: John Wiley \& Sons,inc.

[27]Wiwoho, Ardjuno. (2008). Pengetahuan Tata Hidang. Jakarta: Penerbit Erlangga. 